\title{
Factors that Affect the Content of Cadmium, Nickel, Copper and Zinc in Tissues of the Knee Joint
}

\author{
Wojciech Roczniak $^{1}$ - Barbara Brodziak-Dopierala ${ }^{2}$ - Elżbieta Cipora ${ }^{1}$. \\ Agata Jakóbik-Kolon $^{3}$ • Joanna Kluczka ${ }^{3}$ • Magdalena Babuśka-Roczniak ${ }^{1}$
}

Received: 20 September 2016 / Accepted: 28 December 2016/Published online: 9 January 2017

(C) The Author(s) 2017. This article is published with open access at Springerlink.com

\begin{abstract}
Osteoarthritis causes the degradation of the articular cartilage and periarticular bones. Trace elements influence the growth, development and condition of the bone tissue. Changes to the mineral composition of the bone tissue can cause degenerative changes and fractures. The aim of the research was to determine the content of cadmium (Cd), nickel $(\mathrm{Ni})$, copper $(\mathrm{Cu})$ and zinc $(\mathrm{Zn})$ in the tibia, the femur and the meniscus in men and women who underwent a knee replacement surgery. Samples were collected from 50 patients, including 36 women and 14 men. The determination of trace elements content were performed by ICP-AES method, using Varian 710-ES. Average concentration in the tissues of the knee joint teeth amounted for cadmium 0.015 , nickel 0.60 , copper 0.89 and zinc $80.81 \mathrm{mg} / \mathrm{kg}$ wet weight. There were statistically significant differences in the content of cadmium, copper and zinc in different parts of the knee joint. There were no statistically significant differences in the content of cadmium, nickel, copper and zinc in women and men in the examined parts of the knee joint. Among the elements tested, copper and nickel showed a high content in the connective tissue (the meniscus) compared to the bone tissue (the tibia and the femur).
\end{abstract}

Barbara Brodziak-Dopierała

bbrodziak@sum.edu.pl

1 Medical Institute, The Jan Grodek Higher Vocational State School, 21 Mickiewicza Str. 38-500, Sanok, Poland

2 School of Pharmacy with the Division of Laboratory Medicine, Department of Toxicology, Medical University of Silesia, 4 Jagiellonska Str. 41-200, Sosnowiec, Poland

3 Faculty of Chemistry, Department of Inorganic, Analytical Chemistry and Electrochemistry, Silesian University of Technology, 6 B. Krzywoustego Str. 44-100, Gliwice, Poland
Keywords Cadmium $\cdot$ Nickel $\cdot$ Copper $\cdot$ Zinc $\cdot$ Knee joint . Factors

\section{Introduction}

Osteoarthritis is the most common disorder of the locomotor system and affects mainly the elderly. In $80 \%$ of people over the age of 60 , radiographs show degenerative changes, and $20 \%$ of them suffer from pain and limited mobility. Osteoarthritis may also occur in younger people, before the age of 50, and is considered a serious health problem [1]. It is estimated that approximately $40 \%$ of degenerative changes of the knee joint is related to body ageing, whereas the rest of diseases are due to excessive load and trauma [1-3].

Joint-related ailments are more often the concern of young and active people willing to do sports. Unfortunately, many changes in the joints have a concealed nature, without apparent discomfort. Physical activity is considered beneficial for general health, but there are reports that it may also influence the development of early osteoarthritis [4].

Osteoarthritis is a disease of the joints that involves degradation of the articular cartilage and periarticular bones. Lesions to the articular cartilage and subchondral bones are related to the development and activity of osteoclasts from the subchondral bone [4]. In the course of osteoarthritis, there are more decomposition processes than protein synthesis processes which leads to irreversible changes in the structure of the articular cartilage. As a result, degradation of proteoglycans and collagen fibres occurs [1]. This disease has a multifactorial aetiology [1, 3, 5-8].

According to recent epidemiological data, the incidence of osteoarthritis around the world varies and amounts to $2-15 \%$ of the population. In Poland, the disease affects approximately 7-8 million people; in $40 \%$ of cases, degenerative changes are 
located in the hip joint, and in approximately $25 \%$ in the knee joint [9].

Trace elements as cooper and zinc influence the growth, development and condition of the bone tissue $[10,11]$. Changes to the mineral composition of the bone tissue can cause degenerative changes and fractures. The deficiency of certain trace elements such as zinc, selenium or copper may increase the risk of bone resorption, thus inhibiting bone growth [12].

Zinc protects the body against free radicals, stimulates metallothionein synthesis, stimulates proliferation and differentiation of osteoblasts and regulates the activity of vitamin D. Moreover, it prevents bone resorption that is stimulated by the parathyroid hormone. Zinc deficiency or its excessive loss by kidneys can lead to osteoporosis [13-15].

Copper induces low bone turnover by suppression of both osteoblastic and osteoclastic functions. It is also a co-factor of the lysyl oxidase, vital for cross-linking of collagen and elastin. The elevated concentration of copper in the serum can affect an increase in the copper stakes in the osseous tissue and the correct proprieties of the osseous tissue [16-18].

Environmental exposure to lead and cadmium is associated with the risk of occurrence of a range of chronic diseases associated with ageing, diseases of the cardiovascular system, chronic kidney failure and osteoporosis [19].

Research on the content of trace elements and components of the bone tissue concern mainly the hip joint [15, 20-25], vertebrae [26, 27] and ribs [28-31]. In contrast, research on the knee joint is quite rare $[32,33]$. Therefore, it seems reasonable to undertake research on the content of elements in particular parts of the knee joint, i.e. the tibia, the femur and the meniscus.

The aim of the research was to determine the content of cadmium, nickel, copper and zinc in the tibia, the femur and the meniscus in men and women who underwent a knee replacement procedure (endoprothesoplastic surgery). The study had been selected elements of a recognised function of toxic elements (cadmium, nickel) as well as the importance of physiological (copper and zinc). An analysis of differences in accumulation of selected elements in particular parts of the hip joint was made as well due to the fact that these elements are of different tissue structure. The influence of such factors as the type of studied tissue, sex, age, place of residence (village, town), smoking, occupational exposure and changes in the content of cadmium, nickel, copper and zinc was determined.

\section{Materials and Methods}

The study material included parts of the knee joint obtained during endoprosthesoplasty in the Dr Janusz Daab Hospital of Trauma Surgery in Piekary Śląskie. Biological samples were obtained from patients living in Silesia Province. Samples were collected from 50 patients, 36 women and 14 men. In 26 patients - the right leg and in 24 patients - the left leg were involved. The mean age of the whole study population was 67.5 years, being slightly lower in women -67.2 years than in men- 68.1 years. In the study group, patients complained of pain of 10 years' duration. A detailed description of the test group patients is shown in Table 1 .

The study was approved by the Bioethics Committee No 2/2013 of 18 June 2013. Degenerative disease of the knee joint and considerable pain were indications for this type of procedure. Surgeries were performed in subarachnoid anaesthesia, with patients in the prone position. Esmarch bandage was used for exsanguination of the limb. The frontal surface of the knee joint was exposed following standard preparation of the operation field (applying antiseptic and aseptic techniques) with straight midline incision. The joint was opened at the medial side and the hypertrophic synovium was removed. Using ZIMMER instrumentation, the femoral part of the knee joint was prepared by preparing the distal femur and performing femoral epicondyle osteotomy. Next, damaged menisci were removed, and using a Zimmer instrument, the tibial part was prepared (resection of the tibial plateau). In this way, the osseous components, cartilages and parts of menisci were used for measurements.

The material samples were described and stored in modified polyethylene containers, in a freezer, at a temperature of $-22{ }^{\circ} \mathrm{C}$.

Tissue samples with a known mass were mineralised using $4 \mathrm{~cm}^{3}$ of spectrally pure $\mathrm{HNO}_{3}$ (V) (Supra pure), Merck, in a Magnum II microwave mineraliser, Ertec. The samples were placed one by one in a Teflon vessel and added mineralisation. Mineralisation was a two-stage procedure. The first stage lasted 2 min at 20 bar maximum pressure and $255^{\circ} \mathrm{C}$ maximum temperature, whereas the second stage was of 6 min duration at 45 bar maximum pressure and $285{ }^{\circ} \mathrm{C}$ maximum temperature. The post-mineralisation solution was transferred to a $25-\mathrm{cm}^{3}$ flask and then diluted to the millilitre mark with redistilled water.

The content of cadmium, nickel, copper and zinc in mineralised samples was determined using inductively coupled plasma atomic emission spectrometry (ICP-AES). A Varian 710-ES spectrometer equipped with a OneNeb nebuliser was utilised. The following parameters were used: RF power, $1.0 \mathrm{~kW}$; plasma flow, $15 \mathrm{~L} / \mathrm{min}$; auxiliary flow, $1.5 \mathrm{~L} / \mathrm{min}$; nebuliser pressure, $210 \mathrm{kPa}$; pump rate, $15 \mathrm{rpm}$; emission lines of $\mathrm{Cd}: \lambda=214.439$ and $228.802 \mathrm{~nm}, \mathrm{Ni}$ : $\lambda=231.604 \mathrm{~nm}, \mathrm{Cu}: \lambda=324.754$ and $327.395 \mathrm{~nm}, \mathrm{Zn}$ : $\lambda=206.200$ and $213.857 \mathrm{~nm}$. The calibration curve method was applied. The standard solutions of $1 \mathrm{mg} / \mathrm{mL}$ (Merck Millipore, Germany) as well as deionised water (Millipore Elix 10 system) were used. The results are an average of the concentrations obtained for all analytical lines used for the element, with standard deviation not exceeding $1.5 \%$. The 
Table 1 Information about the study group patients

\begin{tabular}{|c|c|c|c|}
\hline Parameters & $\begin{array}{l}\text { Whole population } \\
n=50\end{array}$ & $\begin{array}{l}\text { Females } \\
n=36\end{array}$ & Males $n=14$ \\
\hline \multicolumn{4}{|l|}{ Age (years) } \\
\hline $\mathrm{AM} \pm \mathrm{SD}$ & $67.46 \pm 7.11$ & $67.22 \pm 7.09$ & $68.07 \pm 7.20$ \\
\hline Range & $54-78$ & $54-78$ & $56-78$ \\
\hline \multicolumn{4}{|l|}{ Body weight (kg) } \\
\hline $\mathrm{AM} \pm \mathrm{SD}$ & $83.54 \pm 14.56$ & $81.45 \pm 14.19$ & $88.58 \pm 14.56$ \\
\hline Range & $54-115$ & $54-115$ & $66-108$ \\
\hline \multicolumn{4}{|l|}{ Height (cm) } \\
\hline $\mathrm{AM} \pm \mathrm{SD}$ & $164.37 \pm 9.32$ & $160.24 \pm 6.14$ & $174.33 \pm 8.11$ \\
\hline Range & 149-189 & $149-173$ & $165-189$ \\
\hline \multicolumn{4}{|l|}{ Smokers $(n, \%)$} \\
\hline - Non-smokers & $20(40 \%)$ & $19(38 \%)$ & $1(2 \%)$ \\
\hline - Smokers & $21(42 \%)$ & $10(20 \%)$ & $11(22 \%)$ \\
\hline - Smokers in the past & $9(18 \%)$ & $5(10 \%)$ & $4(8 \%)$ \\
\hline \multicolumn{4}{|l|}{ Place of residence (\%) } \\
\hline Village & $11(22 \%)$ & $7(14 \%)$ & $4(8 \%)$ \\
\hline Town & $39(78 \%)$ & $29(58 \%)$ & $10(20 \%)$ \\
\hline \multicolumn{4}{|l|}{ Knee $(\%)$} \\
\hline Left & $24(48 \%)$ & $18(36 \%)$ & $6(12 \%)$ \\
\hline Right & $26(52 \%)$ & $18(36 \%)$ & $8(16 \%)$ \\
\hline \multicolumn{4}{|l|}{ Beginning pain (years, \%) } \\
\hline$<5$ & $16(32 \%)$ & $11(22 \%)$ & $5(10 \%)$ \\
\hline$<10$ & $21(42 \%)$ & $15(30 \%)$ & $6(12 \%)$ \\
\hline$>10$ & $13(26 \%)$ & $10(20 \%)$ & $3(9 \%)$ \\
\hline \multicolumn{4}{|l|}{ Earlier knee endoprosthesis (\%) } \\
\hline Yes & $13(26 \%)$ & $10(20 \%)$ & $3(6 \%)$ \\
\hline No & $37(74 \%)$ & $26(52 \%)$ & $11(22 \%)$ \\
\hline \multicolumn{4}{|l|}{ Degenerative changes in the other knee (\%) } \\
\hline Yes & $33(66 \%)$ & $23(46 \%)$ & $10(20 \%)$ \\
\hline No & $17(34 \%)$ & $13(26 \%)$ & $4(8 \%)$ \\
\hline $\begin{array}{l}\text { Contact with chemicals in the workplace (factory } \\
\text { PVC, zinc smelter) }(\%)\end{array}$ & $3(6 \%)$ & $1(2 \%)$ & $2(4 \%)$ \\
\hline
\end{tabular}

accuracy of the analysis was controlled using Standard Reference Material 1400 Bone Ash (NIST).

The statistical analysis was made using the Statistica Pl. 12 software (StatSoft Crocow).

\section{Results}

The contents of $\mathrm{Cd}, \mathrm{Ni}, \mathrm{Cu}$ and $\mathrm{Zn}$ in the tissues of the hip joint did not show a normal distribution, and therefore to calculate the differences, non-parametric tests were used. To assess the differences between the groups, the Mann-Whitney $U$ test was used for two samples and the ANOVA Kruskal-Wallis test by ranks was used for many samples. The level of significance at $p \leq 0.05$ was statistically significant.

There were statistically significant differences in the content of $\mathrm{Cd}, \mathrm{Cu}$ and $\mathrm{Zn}$ in different parts of the knee joint (ANOVA test, $p<0.001$ ). The analysis of the content of $\mathrm{Cd}$ in men and women showed that there is significance in differences between these groups (Mann-Whitney $U$ test, $p=0.03$ ). Cadmium exhibited the lowest content in tissues of the knee joint. The median corresponding to the average content of $\mathrm{Cd}$ in women in the tibia was $0.014 \mathrm{mg} / \mathrm{kg}$, the femur $0.013 \mathrm{mg} / \mathrm{kg}$ and the meniscus $0.007 \mathrm{mg} / \mathrm{kg}$. In men, the contents were slightly higher and amounted to $0.016 \mathrm{mg} / \mathrm{kg}$ in the tibia, $0.017 \mathrm{mg} / \mathrm{kg}$ in the femur and $0.008 \mathrm{mg} / \mathrm{kg}$ in the meniscus.

For $\mathrm{Ni}$, there were no statistically significant differences between the studied tissues. A high amount of Ni was present in tissues of the knee joint in women compared to men. In the tibia in women, Ni was present in the amount of $0.29 \mathrm{mg} / \mathrm{kg}$, and in men, $0.22 \mathrm{mg} / \mathrm{kg}$. However, in the femur in women, the median for Ni was $0.36 \mathrm{mg} / \mathrm{kg}$, and in men, $0.28 \mathrm{mg} / \mathrm{kg}$. In the meniscus in women, it was $0.69 \mathrm{mg} / \mathrm{kg}$, and in men, $0.42 \mathrm{mg} / \mathrm{kg}$.

In women, the lowest $\mathrm{Cu}$ content was $0.36 \mathrm{mg} / \mathrm{kg}$ in the femur, then $0.39 \mathrm{mg} / \mathrm{kg}$ in the tibia and $0.65 \mathrm{mg} / \mathrm{kg}$ in the meniscus. Based on the median, the lowest content in men was in the tibia $(0.31 \mathrm{mg} / \mathrm{kg})$, followed by the femur $(0.46 \mathrm{mg} / \mathrm{kg})$ and in the meniscus $(0.79 \mathrm{mg} / \mathrm{kg})$.

The highest content of the analysed elements was observed for $\mathrm{Zn}$. The median value in the femur was the highest, and in women it was $76.86 \mathrm{mg} / \mathrm{kg}$ and in men $91.68 \mathrm{mg} / \mathrm{kg}$; in the tibia, it was $84.34 \mathrm{mg} / \mathrm{kg}$ in women and $100.35 \mathrm{mg} / \mathrm{kg}$ in men and in the meniscus it was $9.96 \mathrm{mg} / \mathrm{kg}$ in women and $10.74 \mathrm{mg} / \mathrm{kg}$ in men (Table 2).

The studied population included people aged 54 up to 78 years and was divided into three age groups: up to 60 years old, 61-70 years old and over 71 years old. Using the ANOVA 
Table 2 Statistical characteristics for concentration of cadmium, nickel, copper and zinc in tissues of the knee joint ( $\mathrm{mg} / \mathrm{kg}$ )

\begin{tabular}{|c|c|c|c|c|}
\hline & & $\begin{array}{l}\text { Tibia } n=50 \\
\mathrm{AM} \pm \mathrm{SD} \\
\text { Median } \\
\text { Range }\end{array}$ & $\begin{array}{l}\text { Femur } n=50 \\
\mathrm{AM} \pm \mathrm{SD} \\
\text { Median } \\
\text { Range }\end{array}$ & $\begin{array}{l}\text { Meniscus } n=50 \\
\mathrm{AM} \pm \mathrm{SD} \\
\text { Median } \\
\text { Range }\end{array}$ \\
\hline \multirow[t]{10}{*}{$\mathrm{Cd}$} & \multirow[t]{3}{*}{ Men } & $0.019 \pm 0.010$ & $0.017 \pm 0.007$ & $0.012 \pm 0.009$ \\
\hline & & 0.016 & 0.017 & 0.008 \\
\hline & & $0.007-0.047$ & $0.006-0.031$ & $0.006-0.041$ \\
\hline & \multirow[t]{3}{*}{ Women } & $0.015 \pm 0.008$ & $0.014 \pm 0.008$ & $0.009 \pm 0.006$ \\
\hline & & 0.014 & 0.013 & 0.007 \\
\hline & & $0.006-0.049$ & $0.005-0.048$ & $0.005-0.032$ \\
\hline & \multirow[t]{3}{*}{ Whole population } & $0.016 \pm 0.009$ & $0.015 \pm 0.008$ & $0.010 \pm 0.007$ \\
\hline & & 0.015 & 0.013 & 0.008 \\
\hline & & $0.006-0.049$ & $0.005-0.048$ & $0.005-0.041$ \\
\hline & $\mathrm{M}-\mathrm{W}$ & NS & NS & NS \\
\hline \multirow[t]{10}{*}{$\mathrm{Ni}$} & \multirow[t]{3}{*}{ Men } & $0.39 \pm 0.42$ & $0.58 \pm 0.73$ & $0.72 \pm 0.88$ \\
\hline & & 0.22 & 0.28 & 0.42 \\
\hline & & $0.12-1.66$ & $0.12-2.48$ & $0.12-3.47$ \\
\hline & \multirow[t]{3}{*}{ Women } & $0.56 \pm 0.63$ & $0.77 \pm 1.51$ & $0.90 \pm 0.85$ \\
\hline & & 0.29 & 0.36 & 0.69 \\
\hline & & $0.11-3.00$ & $0.10-8.98$ & $0.11-3.04$ \\
\hline & \multirow[t]{3}{*}{ Whole population } & $0.52 \pm 0.58$ & $0.60 \pm 0.69$ & $0.85 \pm 0.86$ \\
\hline & & 0.24 & 0.32 & 0.52 \\
\hline & & $0.11-3.00$ & $0.10-2.98$ & $0.11-3.47$ \\
\hline & M-W & NS & NS & NS \\
\hline \multirow[t]{10}{*}{$\mathrm{Cu}$} & \multirow[t]{3}{*}{ Men } & $0.45 \pm 0.36$ & $0.93 \pm 1.66$ & $0.83 \pm 0.29$ \\
\hline & & 0.31 & 0.46 & 0.79 \\
\hline & & $0.13-1.42$ & $0.19-6.63$ & $0.44-1.44$ \\
\hline & \multirow[t]{3}{*}{ Women } & $0.80 \pm 1.36$ & $0.87 \pm 1.35$ & $0.71 \pm 0.32$ \\
\hline & & 0.39 & 0.36 & 0.65 \\
\hline & & $0.11-6.7$ & $0.11-5.82$ & $0.37-1.61$ \\
\hline & \multirow[t]{3}{*}{ Whole population } & $0.70 \pm 1.17$ & $0.89 \pm 1.43$ & $0.74 \pm 0.31$ \\
\hline & & 0.37 & 0.38 & 0.67 \\
\hline & & $0.11-6.74$ & $0.11-6.63$ & $0.37-1.61$ \\
\hline & $\mathrm{M}-\mathrm{W}$ & NS & NS & NS \\
\hline \multirow[t]{10}{*}{$\mathrm{Zn}$} & \multirow[t]{3}{*}{ Men } & $93.53 \pm 19.89$ & $77.62 \pm 41.74$ & $21.35 \pm 25.59$ \\
\hline & & 100.35 & 91.68 & 10.74 \\
\hline & & $61.93-118.26$ & $4.86-130.71$ & $5.34-92.51$ \\
\hline & \multirow[t]{3}{*}{ Women } & $85.66 \pm 20.77$ & $82.04 \pm 21.26$ & $12.76 \pm 11.94$ \\
\hline & & 84.34 & 76.86 & 9.96 \\
\hline & & $17.05-128.87$ & $49.21-130.20$ & $5.16-78.41$ \\
\hline & \multirow[t]{3}{*}{ Whole population } & $87.86 \pm 20.63$ & $80.81 \pm 28.09$ & $15.17 \pm 17.05$ \\
\hline & & 88.68 & 79.54 & 10.38 \\
\hline & & $17.05-128.87$ & $4.86-130.71$ & $5.16-92.51$ \\
\hline & M-W & NS & NS & NS \\
\hline
\end{tabular}

$A M$ arithmetic mean, $S D$ standard deviation, M-W Mann-Whitney $U$ test, NS non-significant

Kruskal-Wallis test by ranks for many samples, differences in the content of $\mathrm{Cu}$ were shown only $p=0.02$. The largest concentration of $\mathrm{Ni}$ and $\mathrm{Zn}$ was observed in the 61-70-year age group, and in the case of $\mathrm{Cu}$, the largest content occurred in the oldest age group. Differences in Cd content between the three age groups were not observed. Figure 1 shows the nature of changes in $\mathrm{Cd}, \mathrm{Ni}, \mathrm{Cu}$ and $\mathrm{Zn}$ in different age groups.

When comparing the content of elements in the tissues of the knee joint in patients living in rural areas and in cities, no statistically significant differences were found. Patients living in rural areas had lower contents of $\mathrm{Cd}(0.013 \mathrm{vs}$. $0.014 \mathrm{mg} / \mathrm{kg})$, Ni (0.56 vs. $0.64 \mathrm{mg} / \mathrm{kg})$ and $\mathrm{Zn}(56.74$ vs.
$62.56 \mathrm{mg} / \mathrm{kg}$ ), and higher contents of $\mathrm{Cu}(1.12$ vs. $0.68 \mathrm{mg} / \mathrm{kg})$ (Fig. 2).

In the studied population, an increased content of $\mathrm{Cd}$ was observed in smokers $(0.018$ vs. $0.013 \mathrm{mg} / \mathrm{kg})$, but these differences were not statistically significant. A statistically significant difference between smokers and non-smokers was observed for Ni (Mann-Whitney $U$ test, $p=0.026$ ). The content of $\mathrm{Cu}$ and $\mathrm{Ni}$ in the group of smokers was lower than in non-smokers, and for $\mathrm{Ni}$, these values were $0.34 \mathrm{vs}$. $0.64 \mathrm{mg} / \mathrm{kg}$ and 0.45 and $0.75 \mathrm{mg} / \mathrm{kg}$ for $\mathrm{Cu}$, respectively. The content of $\mathrm{Zn}$ was higher for smokers compared to nonsmokers, 71.30 and $60.63 \mathrm{mg} / \mathrm{kg}$, just as in the case of $\mathrm{Cd}$ (Table 3).

Occupational exposure may increase the content of elements in man's tissues. Only $6 \%$ of the studied population was exposed occupationally. In those patients, there was a higher content of $\mathrm{Zn}(71.30$ vs. $60.63 \mathrm{mg} / \mathrm{kg})$ and $\mathrm{Cd}(0.016$ vs. $0.014 \mathrm{mg} / \mathrm{kg}$ ). However, those differences were not statistically significant. However, significance of differences was observed for $\mathrm{Ni}$, where $p=0.07$ (Mann-Whitney $U$ test).

The greatest positive correlations were found between $\mathrm{Cd}-$ $\mathrm{Zn}, \mathrm{Cu}-\mathrm{Ni}$ and $\mathrm{Cu}-$ type of bones. Correlation analysis showed an antagonistic relationship between $\mathrm{Zn}$-type of bones and Cd-type of bones (Table 4).

\section{Discussion}

The use of human tissues, especially those that are acquired in the course of surgeries and are considered medical waste, becomes more frequent. The assessment of the content of metals in bone tissue is used by many researchers to determine the level of exposure. The accumulation of metals is illustrated in the mineral composition of bones, and in the case of some elements such as cadmium and lead, it also indicates the level of exposure in the past. Due to their structure, bones are characterised by a very slow rotation of elements which biological half-lives are estimated to be approximately several to several tens of years [15, 34-37]. The content of elements in bones depends on several factors, including age, sex, place of residence, health status, smoking or diet.

Among the elements tested, $\mathrm{Cu}$ and $\mathrm{Ni}$ showed a high content in the connective tissue (meniscus) compared to the bone tissue (tibial and femur). $\mathrm{Cu}$ plays an important role in the process of production of collagen; therefore, its content in both the bone and connective tissues is high [38-40]. Ni is mainly found in soft tissues; however, its presence in the osseous tissue has also been confirmed. This element influences the skeleton metabolism. In animals, Ni causes growth disorders and contributes to marrow hyperplasia [41].

Comparing the content of elements in tissues of the knee joint, for example, with the content in ribs, there is a higher content of $\mathrm{Cd}, \mathrm{Ni}, \mathrm{Zn}$ and a lower content of $\mathrm{Cu}$ [42]. 

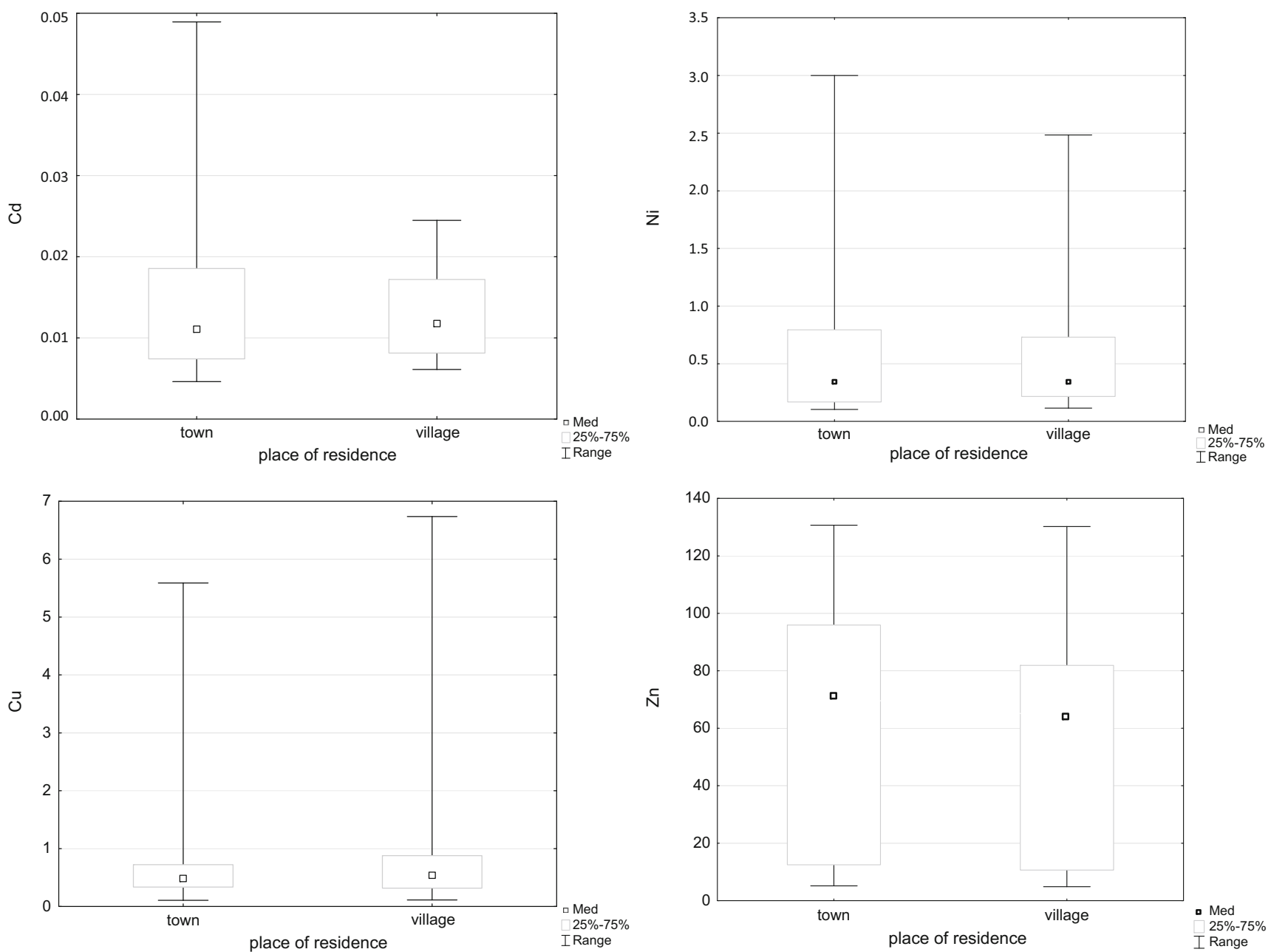

Fig. 1 The occurrence of cadmium, nickel, copper and zinc in tissues of the knee joint, stratified by age

According to Zaichick et al. [29, 30, 43], ribs show higher contents of $\mathrm{Cd}, \mathrm{Ni}$ and $\mathrm{Cu}$, and the content of $\mathrm{Zn}$ in the tibia and the femur was at a similar level.

In case of nickel, most of this element was in the meniscus. However, differences in the content of nickel in different parts of the knee joint are not statistically significant. This means that most of $\mathrm{Ni}$ is accumulated in the connective tissue rather than in the bone tissue. In women, in the tibia there is $38 \%$ less $\mathrm{Cu}$ and in the femur $15 \%$ less $\mathrm{Cu}$ compared to the meniscus. In men, the content of $\mathrm{Cu}$ in the tibia was $46 \%$ lower and in the femur $20 \%$ lower compared to the meniscus.

It was observed that the hip joint showed a $100 \%$ higher content of Cd compared to the knee joint. Łanocha et al. [20] inform that the content of $\mathrm{Cd}$ in the cortical bone and the articular cartilage of the hip joint in women was at the level of 0.026 , and in men, $0.027 \mathrm{mg} / \mathrm{kg}$. This result was similar to the research by Bush et al. [39] $(0.029 \mathrm{mg} / \mathrm{kg})$. Lanocha et al. [42] observed that $\mathrm{Cd}$ concentration in the cortical bone and the articular cartilage of the hip joint did not exceed $0.031 \mathrm{mg} / \mathrm{kg} \mathrm{dw}$. Moreover, there were no significant differences in the concentrations of $\mathrm{Cd}$ between smokers and non-smokers [42].

Based on the conducted studies, it can be observed that the bone tissue had approximately $60 \%$ more $\mathrm{Cd}$ compared to the connective tissue - the meniscus. The content of $\mathrm{Cd}$ in the body is generally higher in women than in men, and this is due to increased gastrointestinal absorption at lower concentrations of iron. However, the conducted studies did not show statistically significant differences in the content of $\mathrm{Cd}$ between men and women: 0.016 and $0.013 \mathrm{mg} / \mathrm{kg}$ ww.

In case of $\mathrm{Cu}$, its content in particular parts of the hip joint was statistically significant (ANOVA test, $p<0.001$ ). Based on the median value, the content of $\mathrm{Cu}$ was highest in the meniscus, which is quite distinctive and specific. The content of $\mathrm{Cu}$ was at a very similar level, which in our study was $0.78 \mathrm{mg} / \mathrm{kg}$ and in the research on the hip joint by Lanocha et al. [19, 42] averaged to a value of $0.79 \mathrm{mg} / \mathrm{kg}$. Zioła-Frankowska et al. [44] observed slightly higher $\mathrm{Cu}$ concentration $(0.90 \mathrm{mg} / \mathrm{kg})$ than in our research $(0.78 \mathrm{mg} / \mathrm{kg})$. Garcia et al. [45] found that $\mathrm{Cu}$ level in bones did not exceed $1.53 \mathrm{mg} / \mathrm{kg}$. 

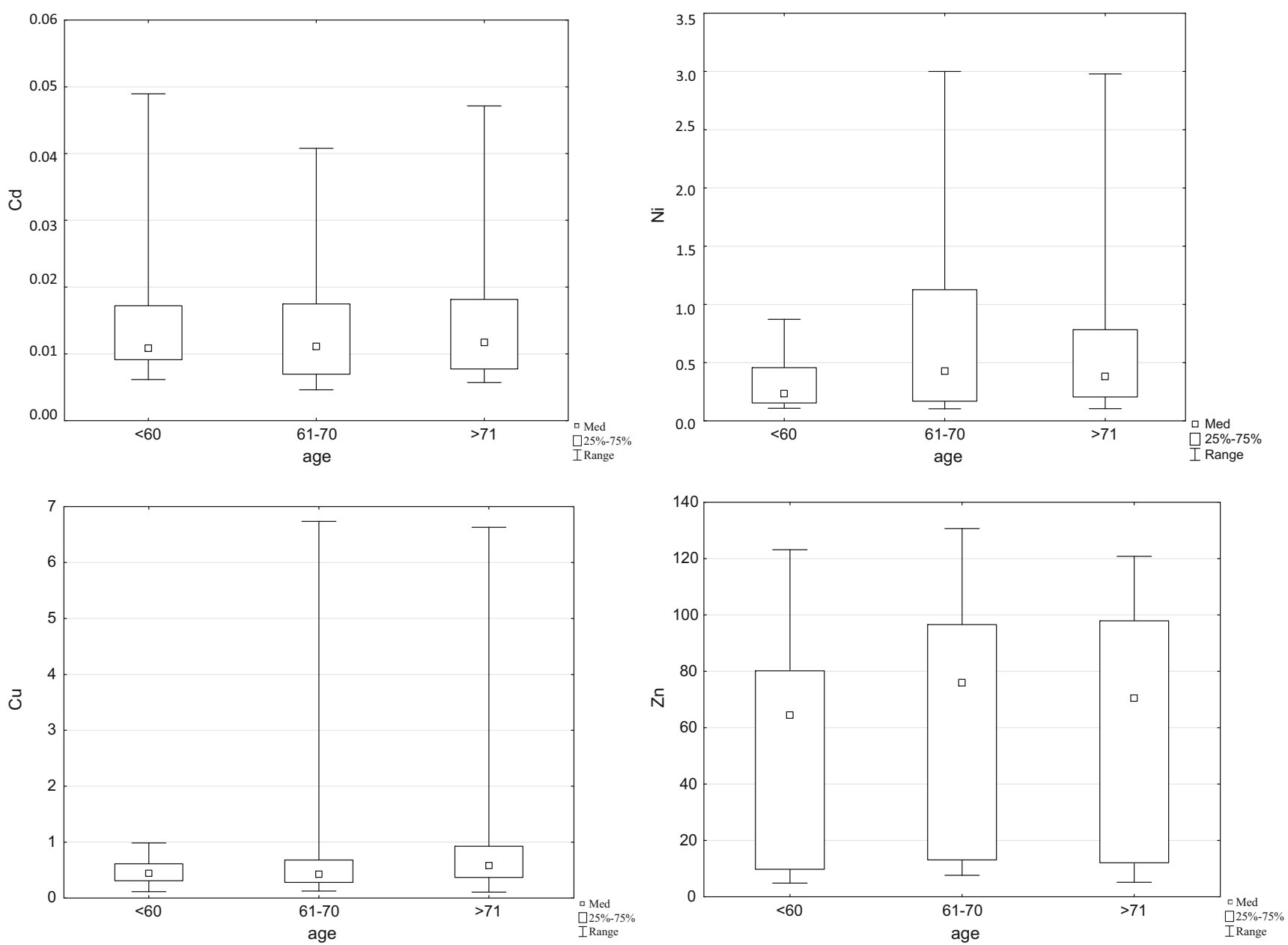

Fig. 2 The occurrence of cadmium, nickel, copper and zinc with residents living in village and town

Table 3 Statistical characteristics for concentration of cadmium, nickel, copper and zinc in tissues of the knee joint (mg/kg)

\begin{tabular}{|c|c|c|c|c|c|c|c|c|}
\hline & $\mathrm{Cd}$ & $\mathrm{Ni}$ & $\mathrm{Cu}$ & $\mathrm{Zn}$ & $\mathrm{Cd}$ & $\mathrm{Ni}$ & $\mathrm{Cu}$ & $\mathrm{Zn}$ \\
\hline & \multicolumn{8}{|c|}{ Place of residence } \\
\hline & \multicolumn{4}{|l|}{ Town $(n=117)$} & \multicolumn{4}{|l|}{ Village $(n=33)$} \\
\hline $\mathrm{AM} \pm \mathrm{SD}$ & $0.014 \pm 0.009$ & $0.64 \pm 0.69$ & $0.68 \pm 0.78$ & $62.56 \pm 39.54$ & $0.013 \pm 0.005$ & $0.56 \pm 0.56$ & $1.12 \pm 1.75$ & $56.74 \pm 40.40$ \\
\hline Median & 0.011 & 0.35 & 0.48 & 71.08 & 0.012 & 0.35 & 0.54 & 63.74 \\
\hline Range & $0.005-0.049$ & $0.10-3.00$ & $0.11-5.59$ & $5.16-130.71$ & $0.006-0.024$ & $0.12-2.48$ & $0.11-6.74$ & $4.86-130.20$ \\
\hline \multicolumn{9}{|l|}{ Smoking } \\
\hline & \multicolumn{4}{|c|}{ Non-smokers $(n=87)$} & \multicolumn{4}{|c|}{ Smokers $(n=63)$} \\
\hline $\mathrm{AM} \pm \mathrm{SD}$ & $0.013 \pm 0.007$ & $0.69 \pm 0.67$ & $0.76 \pm 0.98$ & $61.67 \pm 39.83$ & $0.018 \pm 0.013$ & $0.47 \pm 0.65$ & $0.55 \pm 0.30$ & $59.89 \pm 37.27$ \\
\hline Median & 0.011 & 0.46 & 0.51 & 70.39 & 0.011 & 0.21 & 0.44 & 71.81 \\
\hline Range & $0.005-0.041$ & $0.10-2.98$ & $0.11-6.74$ & $5.16-130.71$ & $0.006-0.049$ & $0.11-3.00$ & $0.18-1.42$ & $6.26-110.50$ \\
\hline \multicolumn{9}{|c|}{ Contact with chemicals in the workplace } \\
\hline & \multicolumn{4}{|l|}{ No $(n=141)$} & \multicolumn{4}{|l|}{ Yes $(n=9)$} \\
\hline $\mathrm{AM} \pm \mathrm{SD}$ & $0.014 \pm 0.009$ & $0.64 \pm 0.67$ & $0.75 \pm 0.94$ & $60.63 \pm 38.40$ & $0.016 \pm 0.011$ & $0.34 \pm 0.43$ & $0.45 \pm 0.25$ & $71.30 \pm 46.49$ \\
\hline Median & 0.011 & 0.42 & 0.53 & 70.39 & 0.011 & 0.16 & 0.42 & 71.08 \\
\hline Range & $0.005-0.049$ & $0.10-3.00$ & $0.11-6.74$ & $5.16-130.20$ & $0.006-0.041$ & $0.12-1.46$ & $0.15-1.02$ & $5.34-130.71$ \\
\hline
\end{tabular}

$A M$ arithmetic mean, $S D$ standard deviation 
Table 4 Spearman's correlation coefficients for cadmium, nickel, copper and zinc from other parameters in tissues of the knee joint

\begin{tabular}{|c|c|c|c|c|c|c|c|c|c|c|c|c|}
\hline Parameters & $\mathrm{Zn}$ & $\mathrm{Ni}$ & $\mathrm{Cu}$ & $\mathrm{Cd}$ & Age & Gender & Place of residence & Knee (left, right) & Body weight & Height & BMI & Smoking \\
\hline $\mathrm{Ni}$ & -0.11 & & & & & & & & & & & \\
\hline $\mathrm{Cu}$ & $-0.29 *$ & $0.45^{*}$ & & & & & & & & & & \\
\hline $\mathrm{Cd}$ & $0.40 *$ & -0.05 & -0.01 & & & & & & & & & \\
\hline Type of bone & $-0.69 *$ & $0.18^{*}$ & $0.36^{*}$ & $-0.39 *$ & & & & & & & & \\
\hline Age & 0.06 & 0.16 & $0.23 *$ & -0.04 & & & & & & & & \\
\hline Gender & 0.06 & -0.11 & 0.04 & $0.18^{*}$ & 0.05 & & & & & & & \\
\hline Place of residence & 0.08 & -0.08 & -0.04 & $-0.19 *$ & -0.07 & $-0.22^{*}$ & & & & & & \\
\hline Knee (left, right) & 0.06 & -0.01 & 0.14 & 0.03 & 0.06 & $-0.06^{*}$ & $0.19^{*}$ & & & & & \\
\hline Body weight & -0.03 & 0.00 & -0.05 & 0.02 & $-0.40 *$ & $0.20 *$ & $-0.19 *$ & 0.01 & & & & \\
\hline Height & 0.04 & 0.01 & 0.05 & 0.13 & -0.01 & $0.68 *$ & $-0.36^{*}$ & -0.16 & $0.52 *$ & & & \\
\hline BMI & -0.03 & 0.00 & -0.05 & 0.02 & $-0.40 *$ & $0.20 *$ & $-0.19 *$ & 0.01 & 1.00 & $0.52 *$ & & \\
\hline Smoking & 0.00 & $0.21^{*}$ & 0.04 & -0.10 & 0.15 & $-0.31 *$ & -0.13 & 0.04 & 0.02 & -0.11 & 0.02 & \\
\hline Beginning pain & -0.10 & 0.07 & 0.05 & 0.01 & 0.14 & -0.03 & -0.04 & $-0.17 *$ & -0.17 & -0.10 & -0.17 & 0.16 \\
\hline
\end{tabular}

$(* p<0.05$, statistically significant

The highest content of $\mathrm{Zn}$ in both women and men was found in the tibia and the lowest in the meniscus; in women, the content of $\mathrm{Zn}$ was higher by $85 \%$, and in men, by $77 \%$. In case of the content of $\mathrm{Zn}$ in selected tissues of the knee joint, there were statistically significant differences (ANOVA test, $p<0.001$ ).

The average content of $\mathrm{Zn}$ in the tibia marked by LanochaArendarczyk et al. [31] was at a similar level at $98.90 \mathrm{mg} / \mathrm{kg}$ when compared to our results $(87.86 \mathrm{mg} / \mathrm{kg})$. Similarly, there were no statistically significant differences in the content of $\mathrm{Zn}$ in men and women, whereas in men they were slightly higher [31].

The content of $\mathrm{Cd}$ in three age groups was at the same level, which may suggest that the reserve of $\mathrm{Cd}$ in human body is subject to constant exchange and no long-term accumulation is present.

The content of $\mathrm{Cd}$ in bones from the industrialised region of Tarragona (Spain) was determined by Garcia et al. [45] to be $0.025 \mathrm{mg} / \mathrm{kg}$, and there were no statistically significant differences between men and women as well as smokers and non-smokers.

Lanocha-Arendarczyk et al. [31], in patients from NW Poland after knee surgery, reported a higher $\mathrm{Cd}$ concentration in men than in women, which is similar to our research. Women's tendency to a greater accumulation of $\mathrm{Cd}$ in comparison with men (0.06 vs. $0.04 \mathrm{mg} / \mathrm{kg})$, which is often quoted in literature $[28,30,46]$, was not confirmed. The content of $\mathrm{Cd}$ indicated by Lanocha-Arendarczyk et al. [31] was higher than our results (0.05 vs. $0.016 \mathrm{mg} / \mathrm{kg})$. There was a higher content of $\mathrm{Cd}$ in the group of smokers compared with non-smokers (0.06 vs. $0.03 \mathrm{mg} / \mathrm{kg}$ ), as also confirmed by the research by Lanocha-Arendarczyk et al. [31].

According to Lanocha-Arendarczyk et al. [46], the content of $\mathrm{Ni}$ in the hip joint was $0.177 \mathrm{mg} / \mathrm{kg}$, and this value was significantly lower compared to the content in the knee joint $(0.76 \mathrm{mg} / \mathrm{kg})$. The content of $\mathrm{Ni}$ in occupationally exposed and unexposed population in the research by LanochaArendarczyk et al. [46] was variable depending on the type of the examined tissue. In the articular cartilage, as in our research, the significance of differences was at a similar level; in the cortical bone, the content of $\mathrm{Ni}$ was higher in the unexposed population, and in the cancellous bone, in the occupationally exposed population. In the hip joint, the content of $\mathrm{Ni}$ identified by Zioła-Frankowska et al. [44] was similar to $0.70 \mathrm{mg} / \mathrm{kg}$.

The content of $\mathrm{Ni}$ in bones from people living in industrialised areas of Spain was $1.20 \mathrm{mg} / \mathrm{kg}$ [45]. Similarly to the results obtained $(0.80$ and $0.64 \mathrm{mg} / \mathrm{kg})$, the content of $\mathrm{Ni}$ was higher in women $(1.474 \mathrm{mg} / \mathrm{kg})$ than in men $(1.20 \mathrm{mg} / \mathrm{kg})$ [41].

The content of $\mathrm{Zn}$ in the tissues of the hip joint in inhabitants of the north-western region of Poland [19, 42] was as follows: the cortical bone with the articular cartilage and cancellous bone- 88.29 and $83.10 \mathrm{mg} / \mathrm{kg}$ dw. The content in the knee joint was at a similar level: the tibia 87.86 and the femur $80.81 \mathrm{mg} / \mathrm{kg}$. Slightly lower values of $\mathrm{Zn}$ were reported by Zioła-Frankowska et al. [44], and this concerned the hip joint of people from the Greater Poland Province; in the cortical bone it was $72.09 \mathrm{mg} \mathrm{Zn/kg}$, and in the cancellous bone, $68.7 \mathrm{mg} \mathrm{Zn} / \mathrm{kg}$. In the research by Brodziak et al. [15], the content of $\mathrm{Zn}$ in the cortical bone was at a similar level as in the knee joint.

According to research on the territory of Spain published by Garcia et al. [45], the content of $\mathrm{Zn}$ in bones was $39.40 \mathrm{mg} / \mathrm{kg}$.

$\mathrm{Cd}$ and $\mathrm{Zn}$ are among the elements with proven antagonistic relations because $\mathrm{Cd}$ ions inhibit intestinal absorption of $\mathrm{Zn}$ 
among others $[15,47]$. The conducted correlation analysis between the two elements showed significant synergistic correlations between $\mathrm{Cd}$ and $\mathrm{Zn}(r=0.40$, Spearman $p<0.05)$. Nickel may have both synergistic and antagonistic correlations with most elements, whereas $\mathrm{Cu}$ correlates antagonistically with $\mathrm{Zn}$ [47]. In the obtained research results, nickel correlated with $\mathrm{Cu}(r=0.45)$. For $\mathrm{Cu}$, antagonistic relations between $\mathrm{Cu}$ and $\mathrm{Zn}$ were confirmed $(-0.29)$. Cd-Zn correlations were not confirmed by Lanocha et al. [31] and Kuo et al. [48]. In the research by Kuo et al. [48], the same correlation as in our research $-\mathrm{Ni}-\mathrm{Cu}(r=0.57)$ - was observed. The correlation between nickel and $\mathrm{Cu}$ was confirmed in the research by Zioła-Frankowska et al. [44] both in the cortical bone $(r=0.57)$ and the cancellous bone (0.44).

\section{Conclusions}

There were statistically significant differences in the content of cadmium, copper and zinc between the examined tissues, i.e. the tibia, the femur and the meniscus. Among the elements tested, copper and nickel showed a high content in the connective tissue (the meniscus) compared to the bone tissue (the tibia and the femur).

There were no statistically significant differences in the content of cadmium, nickel, copper and zinc in women and men in the examined parts of the hip joint.

One of the most common correlations described in literature that was confirmed is the synergistic correlation between nickel and copper.

The content of cadmium in tissues of the knee joint was significantly lower as compared with the hip joint, and the content of zinc was at a similar level.

The content of cadmium in three age groups was at the same level, which may suggest that the reserve of cadmium in the human body is subject to constant exchange and no long-term accumulation is present.

The population of occupationally exposed people showed higher contents of zinc and cadmium.

\section{Compliance with Ethical Standards}

Conflict of Interest The authors declare that they have no competing interests.

Open Access This article is distributed under the terms of the Creative Commons Attribution 4.0 International License (http:// creativecommons.org/licenses/by/4.0/), which permits unrestricted use, distribution, and reproduction in any medium, provided you give appropriate credit to the original author(s) and the source, provide a link to the Creative Commons license, and indicate if changes were made.

\section{References}

1. Chojnacki M, Kwapisz A, Synder M, Szemraj J (2014) Osteoarthritis: etiology, risk factors, molecular mechanisms. Postepy Hig Med Dosw 68:640-652

2. Mika A, Polak P (2007) The use of high-tone power therapy in the rehabilitation of patients with coxarthrosis. Fizjoterapia Polska 4: 401-408

3. Ogrodzka K, Chwała W, Niedźwiedzki T (2007) Threedimensional pattern of knee movement in patients with gonarthrosis. Ortop Traumatol Rehabil 6:618-626

4. Vannini F, Spalding T, Andriolo L, Berruto M, Denti M, Espregueira-Mendes J, Menetrey J, Peretti GM, Seil R, Filardo G (2016) Sport and early osteoarthritis: the role of sport in aetiology, progression and treatment of knee osteoarthritis. Knee Surg Sports Traumatol Arthrosc 24:1786-1796. doi:10.1007/s00167-0164090-5

5. Kaufman KR, Huges C, Morrey BF, Morrey M, An KN (2001) Gait characteristics of patients with knee osteoarthritis. J Biomech 34: 907-915

6. Li X, Yang J, Liu D, Li J, Niu K, Feng S, Yokota H, Zhang P (2016) Knee loading inhibits osteoclast lineage in a mouse model of osteoarthritis. Sci Rep 6:24668. doi:10.1038/srep24668

7. Gajewski T, Woźnica I, Młynarska M, Ćwikła S, Strzemecka J, Bojar I (2013) Wybrane aspekty jakości życia osób ze zmianami zwyrodnieniowymi kręgosłupa i stawów. Medycyna Ogólna i Nauki o Zdrowiu 19:362-369

8. Leszczyński P, Pawlak-Buś K (2008) Osteoarthritis - the epidemic of the 21st century. Farmacja Współczesna 1:79-87

9. Deszczyński J, Sitarz-Szefer A, Kurowska E, Bronikowski A (2010) The application of unicompartmental and total knee replacement in treatment of knee joint degenerative changes. Artroskop Chir Stawów 6:9-15

10. Gür A, Colpan L, Nas K, Cevik R, Sarac J, Erdoğan F, Düz MZ (2002) The role of the trace minerals in the pathogenesis of postmenopausal osteoporosis and a new effect of calcitonin. J Bone Miner Metab 20:39-43

11. Sadeghi N, Oveisi MR, Jannat B, Hajimahmoodi M, Behzad M, Behfar A, Sadeghi F, Saadatmand S (2014) The relationship between bone health and plasma zinc, copper lead and cadmium concentration in osteoporotic women. J Environ Health Sci Eng 12: 125. doi:10.1186/s40201-014-0125-3

12. Wang T, Wen CY, Yan CH, Lu WW, Chiu KY (2013) Spatial and temporal changes of subchondral bone proceed to microscopic articular cartilage degeneration in guinea pigs with spontaneous osteoarthritis. Osteoarthr Cartil 21:574-581

13. Rossi L, Migliaccio S, Corsi A, Marzia M, Bianco P, Teti A, Gambelli L, Cianfarani S, Paoletti F, Branca F (2001) Reduced growth and skeletal changes in zinc-deficient growing rats are due to impaired growth plate activity and inanition. J Nutr 131:1142-1146

14. Yamaguchi M, Ehara Y (1996) Effect of essential trace metal on bone metabolism in the femoral-metaphyseal tissues of rats with skeletal unloading: comparison with zinc-chelating dipeptide. Calcif Tissue Int 59:27-32

15. Brodziak-Dopierała B, Kwapuliński J, Sobczyk K, Wiechuła D (2015) Analysis of the content of cadmium and zinc in parts of the human hip joint. Biol Trace Elem Res 163:73-80. doi:10.1007/s12011-014-0168-4

16. Brodziak-Dopierała B, Kwapuliński J, Paukszto A, Kowol J, Bogunia M, Ahnert B (2009) Interactions of copper and iron with other elements in the osseous tissue of the femur head. Fres Environ Bull 18:1963-1966

17. Howard G, Andon M, Bracker M, Saltman P, Strause L (1992) Low serum copper, a risk factor additional to low dietary calcium in postmenopausal bone loss. J Trace Elem Exp Med 5:23-31 
18. García-Esquinas E, Navas-Acien A, Pérez-Gómez B, Artalejo FR (2015) Association of lead and cadmium exposure with frailty in US older adults. Environ Res 137:424-431

19. Lanocha N, Kalisinska E, Kosik-Bogacka DI, Budis H, Sokolowski S, Bohatyrewicz A (2012) Concentrations of trace elements in bones of the hip joint from patients after hip replacement surgery. J Trace Elem Med Biol 26:20-25

20. Łanocha N, Kalisińska E, Kosik-Bogacka D, Budis H, Sokołowski S, Bohatyrewicz A (2012) Comparison of concentrations of lead and cadmium in various parts of the femur head in patients after arthroplasty of the hip joint in Northwest Poland. Biomed Environ Sci 25:577-582

21. Huttu MRJ, Puhakka J, Mäkelä JTA, Takakubo Y, Tiitu V, Saarakkala S, Konttinen YT, Kiviranta I, Korhonen RK (2014) Cell-tissue interactions in osteoarthritic human hip joint articular cartilage. Connect Tissue Res 55:282-291

22. Brodziak-Dopierała B, Kwapuliński J, Sobczyk K, Wiechuła D (2013) The content of manganese and iron in hip joint tissue. J Trace Elem Med Biol 27:208-212. doi:10.1016/j. jtemb.2012.12.005

23. Brodziak-Dopierała B, Kwapuliński J, Sobczyk K, Wiechuła D (2013) Distribution of magnesium, calcium, sodium and potassium in tissues of the hip joint. Magnes Res 26:125-131. doi:10.1684 /mrh.2013.0348

24. Brodziak-Dopierała B, Kwapuliński J, Sobczyk K, Wiechuła D (2015) Chromium content in the human hip joint tissues. Biomed Environ Sci 28:89-96. doi:10.3967/bes2015.011

25. Kubaszewski Ł, Zioła-Frankowska A, Frankowski M, Rogala P, Gasik Z, Kaczmarczyk J, Nowakowski A, Dabrowski M, Labedz W, Mięksisiak G (2014) Comparison of trace element concentration in bone and intervertebral disc tissue by atomic absorption spectrometry techniques. J Orthop Surg Res 9:99

26. Nowakowski A, Kubaszewski Ł, Frankowski M, Wilk-Frańczuk M, Zioła-Frankowska A, Czabak-Garbacz R, Kaczmarczyk J, Gasik R (2015) Analysis of trace element in intervertebral disc by atomic absorption spectrometry techniques in degenerative disc disease in the Polish population. Ann Agric Environ Med 22: 362-367. doi:10.5604/12321966.1152096

27. Tzaphlidou M, Zaichick V (2003) Calcium, phosphorus, calciumphosphorus ratio in rib bone of healthy humans. Biol Trace Elem Res 93:63-74

28. Zaichick V, Zaichick S, Karandashev V, Nosenko S (2009) The effect of age and gender on $\mathrm{Al}, \mathrm{B}, \mathrm{Ba}, \mathrm{Ca}, \mathrm{Cu}, \mathrm{Fe}, \mathrm{K}, \mathrm{Li}, \mathrm{Mg}$, $\mathrm{Mn}, \mathrm{Na}, \mathrm{P}, \mathrm{S}, \mathrm{Sr}, \mathrm{V}$, and $\mathrm{Zn}$ contents in rib bone of healthy humans. Biol Trace Elem Res 129:107-115

29. Zaichick S, Zaichick V, Karandashev VK, Moskvina IR (2011) The effect of age and gender on 59 trace-element contents in human rib bone investigated by inductively coupled plasma mass spectrometry. Biol Trace Elem Res 143:41-57. doi:10.1007/s12011-010$8837-4$

30. Yoshinaga J, Suzuki T, Morita M, Hayakawa M (1995) Trace elements in ribs of elderly people and elemental variation in the presence of chronic diseases. Sci Total Environ 162:239-252

31. Lanocha-Arendarczyk N, Kosik-Bogacka DI, Prokopowicz A, Kalisinska E, Sokolowski S, Karaczun M, Zietek P, Podlasińska J, Pilarczyk B, Tomza-Marciniak A, Baranowska-Bosiacka I, Gutowska I, Safranow K, Chlubek D (2015) The effect of risk factors on the levels of chemical elements in the tibial plateau of patients with osteoarthritis following knee surgery. Biomed Res Int 650282. doi: $10.1155 / 2015 / 650282$
32. Łanocha-Arendarczyk N, Kosik-Bogacka DI, Kalisińska E, Sokołowski S, Lebiotkowski M, Baranowska-Bosiacka B, Gutowska I, Chlubek D (2015) Bone fluoride content in patients after hip and knee joint surgery. Fluoride 48:223-233

33. Brodziak-Dopierała B, Kowol J, Kwapuliński J, Kusz D, Cieliński $€$ (2011) Lead and calcium content in the human hip joint. Biol Trace Elem Res 144:6-16. doi:10.1007/s12011-011-9014-0

34. Järup L, Alfvén T (2004) Low level cadmium exposure, renal and bone effects - the OSCAR study. Biometals 17:505-509. doi:10.1023/B:BIOM.0000045729.68774.a1

35. Vahter M, Akesson A, Lidén C, Ceccatelli S, Berglund M (2007) Gender differences in the disposition and toxicity of metals. Environ Res 104:85-95

36. Nordberg GF, Fowler BA, Nordberg M, Friberg L (2007) Handbook on the toxicology of metals, 3rd edn. Academic, London, Amsterdam, Bulingtow, San Diego

37. Järupa L, Åkesson A (2009) Current status of cadmium as an environmental health problem. Toxicol Appl Pharm 238:201-208. doi:10.1016/j.taap.2009.04.020

38. Berglund M, Akesson A, Bjellerup P, Vahter M (2000) Metal-bone interactions. Tox Let 112-113:219-225

39. Bush VJ, Moyer TP, Batts KP, Parisi JE (1995) Essential and toxic element concentrations in fresh and formalin-fixed human autopsy tissues. Clin Chem 41:284-294

40. Nielsen FH, Lukaski HC, Johnson LAK, Roughead ZK (2011) Reported zinc, but not copper, intakes influence whole-body bone density, mineral content and $\mathrm{T}$ score responses to zinc and copper supplementation in healthy postmenopausal women. Brit J Nutr 106:1872-1879. doi:10.1017/S0007114511002352

41. Brodziak-Dopierała B, Kwapuliński J, Okrajni J, Kowol J, Kosterska E, Suchy A, Sobczyk K (2007) The estimation of nickel interaction with other elements in an osseous tissue of femur head. Acta Toxicol 15:69-74

42. Lanocha N, Kalisinska E, Kosik-Bogacka DI, Budis H, Sokolowski S, Bohatyrewicz A, Lanocha A (2013) The effect of environmental factors on concentration of trace elements in hip joint bones of patients after hip replacement surgery. Ann Agric Environ Med 20:487-493

43. Zaichick S, Zaichick V (2010) The effect of age and gender on 38 chemical element contents in human femoral neck investigated by instrumental neutron activation analysis. Biol Trace Elem Res 137: $1-12$

44. Zioła-Frankowska A, Kubaszewski Ł, Dąbrowski M, Kowalski A, Rogala P, Strzyżewski W, Łabędź W, Uklejewski R, Novotny K, Kanicky V, Frankowski M (2015) The content of the 14 metals in cancellous and cortical bone of the hip joint affected by osteoarthritis. Biomed Res Int 815648:23. doi:10.1155/2015/815648

45. Garcia F, Ortega A, Domingo JL, Corbella J (2001) Accumulation of metals in autopsy tissues of subjects living in Tarragona county, Spain. J Environ Sci Health 36:1767-1786

46. Łanocha-Arendarczyk N, Kalisińska E, Kosik-Bogacka D, Budis H, Lewicka K, Sokołowski S, Dobiecki K, Kołodziej Ł (2016) Effect of environmental parameters on the concentration of nickel $\mathrm{Ni}$ in bones of the hip joint from patients with osteoarthritis. J PreClin Clin Res 10:6-11

47. Kabata-Pendias A, Pendias H (1999) Biogeochemia pierwiastków śladowych. PWN Warszawa

48. Kuo HW, Kuo SM, Chou CH, Lee TC (2000) Determination of 14 elements in Taiwanese bones. Sci Total Environ 255:45-55 